\title{
The selling of NERC research
}

THE smallest source of Natural Environment Research Council (NERC) income casts a disproportionately large shadow. Private sector and overseas government contracts account for only $£ 3-4$ million out of a $£ 94$ million budget; yet, as NERC chairman Hugh Fish emphasizes, "bolting on some consideration of commercialization" is an important priority for NERC strategic research. These activities give Britain's brightest scientific lights overseas experience, which Mr Fish thinks important, and, more to the point, "it is in the national interest that research should be applied as quickly as possible to earn the country money".

What NERC is selling is expertise in applying research to specific technical problems; in contrast, the marketability of hardware that stands alone is of almost minimal interest. Such a priority points to the developing world as an obvious NERC market, one which many of its institutes

\section{US troops and AIDS}

Washington

The US Department of Defense (DOD) will from 1 September require civilian blood banks to disclose the names of active-duty personnel whose blood tests positively for antibodies to the acquired immune deficiency syndrome (AIDS) virus. The blood banks have agreed only reluctantly to comply with the DOD request.

Blood banks such as the American Red Cross plan to inform potential military donors, before their blood is taken, that results of tests may be passed on to military authorities; details of how the policy will be implemented have yet to be settled. But the spectre of military donors refusing en masse to give blood as a result has become a source of anxiety for blood banks, some of which obtain a substantial proportion of their blood donations from servicemen.

DOD argues that knowing who has been exposed to the AIDS virus could be important for service readiness; for example, vaccinations given routinely to servicemen could be dangerous to those with immune deficiencies. Homosexual rights advocates, who represent one of the high-risk groups for AIDS, protest that unless kept confidential, information from AIDS antibody tests could be used to stigmatize or discriminate against those who have evidence of antibodies, even though many of these may not be infectious and only a small proportion are likely to develop overt disease. The link between AIDS and intravenous drug abuse might also lead to stigma. But DOD, which is separately considering its own mass screening of military personnel for AIDS antibodies, says that test results will be used only for medical evaluation and counselling.

Tim Beardsley

\section{are now exploiting}

While some of this work is directly contracted with foreign governments, $\mathrm{Mr}$ John Morris, senior executive officer of NERC's marketing group, says that a preferred arrangement is a collaboration with a consultant group. The consultants are then responsible to the government or world-aid source for long-term monitoring, logistics and penalty clauses, leaving NERC only as a subcontractor of technical know-how.

The Institute of Terrestrial Ecology (ITE) is a NERC organization that has been involved in contract work for over 10 years. According to Professor Fred Last, ITE deputy director, ITE's experience with contracting has now given it the freedom to choose contracts that fit into its fundamental science programme. He is concerned, however, that few of these contracts have room for a supplement to support basic research; in real money terms, contracts have not yet made up for the decreases in the basic science budget, leading to a "burning up of the resources" on which contracts are based.

The organizational embodiment of NERC's commitment to marketing its strategic and applied research is its $\mathrm{Re}$ search Marketing Group, which is divided into two parts. The first, which Mr Morris calls "science push", involves finding the NERC projects with exploitable applied research and then working out possible logistics, such as, for example, offering a commercial client the resources of several NERC institutes rather than a single project. The "demand-pull" side, on the other hand, keeps up with the priorities of world-aid funding agencies. Mr Morris claims that far from endangering NERC objectivity by private funding, NERC actually has an edge by offering companies what they do not want to hear as well as what they do. The research group, says $\mathrm{Mr}$ Morris, has not been around long enough to judge its effect in financial terms; but the group has had a clear influence in developing "an enthusiam for a balanced push into commercialism" among NERC institutes.

Examples of this balanced push include efforts by the Institute of Marine Environmental Research to form a joint company for the assessment and exploitation of marine resources concentrating on lowlevel toxicity testing, marine surveys and mathematical modelling.

Another is the GLORIA sidescan sonar system for mapping the ocean floor, developed by the Institute of Oceanographic Sciences. In cooperation with the US Geological Survey, IOS has been using GLORIA to map the 200-mile economic exclusive zone off the west coast of the United States, with plans for this year covering the Gulf of Mexico and Puerto
Rico. As with other NERC marketing efforts, GLORIA is portrayed as essentially the selling of expertise.

A year ago, NERC, the largest single contractor for DG XII, the European Commission's directorate responsible for science research and development, set up a Brussels branch of its Research Marketing Group to liaise with the Commission.

Elizabeth Collins

British Association

\section{Scottish meeting}

BILLED as a festival of science, the annual meeting of the British Association for the Advancement of Science (BA) will be held on 26-30 August at the University of Strathclyde in Glasgow. Roughly 1,500 members are expected to attend, with day visitors and school parties bringing that number up to nearly 3,000 .

Exploitation of research is the meeting's primary theme. Over half the papers offered will touch on this topic, including sessions on opportunities in British engineering, engineering in agriculture and the art of forestry. Applied science is also a year-round concern for the $\mathrm{BA}$, as shown by its science and industry committee and increasing corporate interest in the organization. Corporate membership fees have risen more than fourfold over the past year, from $£ 6,221$ in $1983-84$ to $£ 25,850$ in $1984-85$.

Another principal theme of the meeting, waste disposal, will be covered by the $\mathrm{BA}$ debate on disposal of radioactive waste as well as papers on energy recovery from refuse incineration, geochemical aspects of acid rain, waste disposal and energy, and pollution in the sea. Those interested in the third theme, population, can attend lectures on the biosocial aspects of Scottish migration, breeding in the sea, urban policy issues, and contraception and the control of fertility.

Three BAYS (BA Young Scientists) lectures will be offered, on all-optical digital circuits and the future optical computer, vision and movement and superficial chemistry. Other activities have also been planned to interest the roughly 500 expected BAYS visitors to the meeting.

Sir George Porter will be elected president of the BA on the last day of the meeting. The BA budget has increased by roughly $£ 34,000$ this year, from $£ 289,351$ in 1983-84 to $£ 324,330$ in 1984-85.

Elizabeth Collins

\section{Correction: New Zealand science}

SPENDING on research and development in New Zealand in 1984-85 amounts to \$NZ200 million by government, \$NZ68 million by universities and $\$ 150$ million by industry. These figures were given incorrectly in the supplement on Science in Australasia (Nature 18 July, p.187). 